\title{
Effect of current on biofilm-electrode reactor coupled with sulfur autotrophic denitrification process (BER-SAD) for nitrate removal from wastewater
}

\author{
Hengyuan Liu $^{1 *}$ and Chenhe Zhang ${ }^{2}$ \\ ${ }^{1}$ College of Chemistry and Life Sciences, Chifeng University, Chifeng, Inner Mongolia, 024000, China \\ ${ }^{2}$ Chifeng University, Chifeng, Inner Mongolia, 024000, China
}

\begin{abstract}
The biofilm-electrode reactor coupled with sulfur autotrophic denitrification process (BER-SAD) was used to remove nitrate in groundwater, and the effect of current intensity on the denitrification characteristics of the coupled process was explored. Current intensity had a great influence on the denitrification effect of the coupled process, the maximum nitrate removal efficiency of $99.9 \%$ and lowest nitrite production were gained under the optimum current density of $100 \mathrm{~mA}$. Moreover, the accumulation concentration of $\mathrm{SO}_{4}{ }^{2-}$ increased gradually with the increase of current intensity. With the increase of current intensity, the proportion of hydrogen autotrophic denitrification decreased, while the proportion of sulfur autotrophic denitrification increased.
\end{abstract}

\section{Introduction}

Nitrate was considered to be a ubiquitous contaminant of natural water resources and has several sources, such as synthetic and natural fertilization, bacterial production, atmospheric deposition, and leaking septic systems. This worldwide pollution not only affected aquatic ecosystems, but could also pose threat to human health[1]. High levels of nitrate in drinking water, which was converted to nitrite in the human gut, could cause blue baby syndrome in infants and gastrointestinal cancer in adults [2]. Therefore, the maximum contaminant level (MCL) for nitrate stipulated by the World Health Organization (WHO, 2008) is at $11.29 \mathrm{mg}-\mathrm{N} / \mathrm{L}$ in drinking water, and the value proposed by China is $10 \mathrm{mg}-\mathrm{N} / \mathrm{L}$ (Standards for Drinking Water Quality, China: GB5749-2006). Various conventional methods have been used for nitrate removal, such as chemical processes and physicochemical approaches, but some of the methods still need further treatment and could incur high costs[3]. Compared with other methods, biological method has the characteristics of high efficiency and low energy consumption, so the method of removing nitrate in water by biological denitrification has been more and more applied[4].

The biofilm-electrode reactor (BER), which combined electrochemistry and biological denitrification, has become a promising technology due to high efficiency and low investment costs[5]. However, traditional BERs consumed a lot of electrical energy to produce sufficient $\mathrm{H}_{2}$, nitrate removal capacity might be restricted by the surface area of cathode, and denitrification process was easily affected by current[6]. In order to further improve denitrification efficiency and reduce the consumption of electric energy in BER, the BER coupled with sulfur autotrophic denitrification process (BER-SAD) has been developed to treat nitrate polluted water. In the coupling system, the sulfur autotrophic microorganism can use the sulfur element as electron donor, and autotrophic microorganisms can utilize the hydrogen produced by cathode as electron donor.

The current intensity is a key factor affecting the nitrogen removal efficiency of BER-SAD, which directly determines the hydrogen production rate on the cathode surface. At the same time, microorganisms played a vital role in the bio-electrochemical reactors, which in turn were affected by some environmental parameters. The change of current intensity can also cause the change of nitrate reductase activity in autotrophic denitrifying bacteria, suitable electro-stimulation has a positive effect on bacteria by promoting their metabolism and activity[7]. On the other hand, high electro-stimulation could also have negative effects on bacteria, thus affecting the nitrogen removal efficiency of the coupling system[8].

Therefore, in this study, a biofilm-electrode reactor coupled with sulfur autotrophic denitrifification process (BER-SAD) was developed: (1) determine the optimum current density by investigating nitrate removal efficiency under different current intensities, and (2) investigate the proportion of hydrogen autotrophic denitrification and sulfur autotrophic denitrification in the coupled system.

*Corresponding author's e-mail: liuhy729@cugb.edu.cn 


\section{Materials and Methods}

\subsection{Experimental apparatus}

The experimental apparatus consisted of a BER-SAD reactor (a cylinder reactor, an anode and a cathode) and a DC regulated power supply. The hydraulic retention time (HRT) was set at $8 \mathrm{~h}$ and the temperature of BER-SAD was maintained at $30{ }^{\circ} \mathrm{C}$.

\subsection{Synthetic wastewater preparation}

Synthetic wastewater was prepared by dissolving $\mathrm{NaNO}_{3}$, $\mathrm{KH}_{2} \mathrm{PO}_{4}$ and $\mathrm{NaHCO}_{3}$ in a liter of tap water. Then sulfur particles $(2-3 \mathrm{~mm})$ were added to the reactor as electron donors. The concentration of $\mathrm{NO}_{3}{ }^{-}-\mathrm{N}$ was prepared as $50.00 \mathrm{mg} / \mathrm{L}$. The original $\mathrm{pH}$ was around the range of 7.25 \pm 0.02 and needed no further adjustment.

\subsection{Analytical methods}

Nitrate-N and Nitrite-N was determined using an ultraviolet spectrophotometer according to the Water and Wastewater Monitoring Analysis Method (SEPA, 2002). The $\mathrm{SO}_{4}{ }^{2-}$ was determined by ionic chromatography.

\section{Results \& Discussion}

\subsection{Nitrate removal}

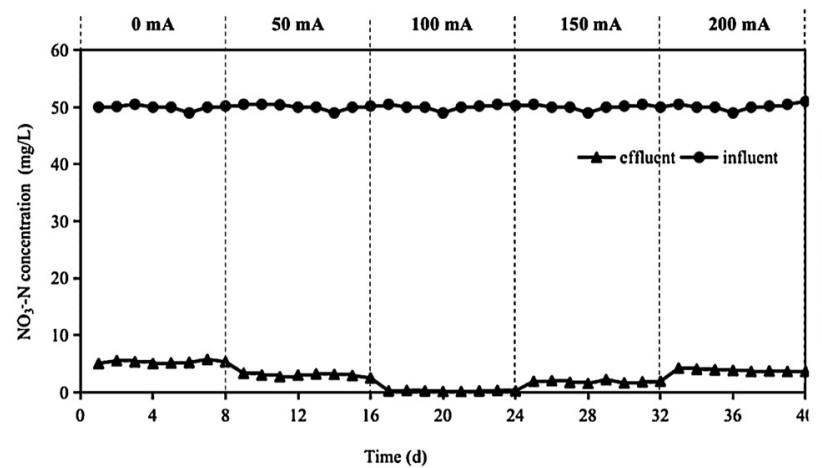

As shown in Figure 1, $\mathrm{NO}_{3}^{-}-\mathrm{N}$ could be reduced under different current intensities. The $\mathrm{NO}_{3}^{-}-\mathrm{N}$ concentrations in influent were $50 \pm 0.90 \mathrm{mg} / \mathrm{L}$ at all current intensities. When the applied current intensity was increased incrementally up to $100 \mathrm{~mA}, \mathrm{NO}_{3}^{-}-\mathrm{N}$ concentration in effluent was decreased accordingly. The average concentration of $\mathrm{NO}_{3}^{-}-\mathrm{N}$ in effluent were 5.31, 3,02 and $0.24 \mathrm{mg} / \mathrm{L}$ at 0,50 and $100 \mathrm{~mA}$, respectively. The maximum nitrate reduction efficiency was $99.9 \%$ at 100 $\mathrm{mA}$. When the applied current intensity was further raised to higher than $100 \mathrm{~mA}$, the average $\mathrm{NO}_{3}^{-}-\mathrm{N}$ concentration in effluent increased, especially when the current intensity increased to $200 \mathrm{~mA}$, the concentration of $\mathrm{NO}_{3}{ }^{-} \mathrm{N}$ was raised rapidly. The average concentration of $\mathrm{NO}_{3}^{-}-\mathrm{N}$ in effluent were 1.82 and $3.60 \mathrm{mg} / \mathrm{L}$ at 150 and $200 \mathrm{~mA}$, respectively.

The $\mathrm{NO}_{3}^{-}-\mathrm{N}$ concentration in the reactor might be due to the following reasons: (1) the increase of current intensity can promote the formation of more hydrogen on the cathode surface and accelerate the formation of more $\mathrm{CO}_{2}$ by anode graphite rod electrolysis, thus providing more electron donors and inorganic carbon sources for autotrophic microorganisms; (2) the increase of current intensity can stimulate the activity of nitrate reductase in autotrophic microorganism, thus promoting the utilization of electronic donor $\mathrm{H}_{2}$ and $\mathrm{S}$, and improving denitrification efficiency of the system; (3) while higher current intensity has a lethal influence on denitrifying bacteria, which finally decreased the denitrification performance[9].

Figure 1. Effect of current intensity on $\mathrm{NO}_{3}{ }^{-}-\mathrm{N}$ removal, $\mathrm{NO}_{2}{ }^{-}-\mathrm{N}$ and $\mathrm{SO}_{4}{ }^{2}$ concentration

\subsection{Nitrite and sulfate accumulation}

$\mathrm{NO}_{2}^{-}-\mathrm{N}$ change could attribute to the denitrification processes(i.e. $\mathrm{NO}_{3}^{-} \rightarrow \mathrm{NO}_{2}^{-} \rightarrow \mathrm{NO}^{-} \rightarrow \mathrm{N}_{2} \mathrm{O} \rightarrow \mathrm{N} 2$ ), in which nitrite was the intermediate byproduct[10]. Variation of $\mathrm{NO}_{2}^{-}-\mathrm{N}$ concentrations in different applied current intensities was also tested and showed in Figure 1. The initial $\mathrm{NO}_{2}^{-}-\mathrm{N}$ concentration in influent was less than $0.02 \mathrm{mg} / \mathrm{L}$ in all set-ups. When no current applied, the $\mathrm{NO}_{2}^{-}-\mathrm{N}$ concentration accumulations of $2.01 \mathrm{mg} / \mathrm{L}$. When the current intensity was 50, 100, 150 and $200 \mathrm{~mA}, \mathrm{NO}_{2}^{-}-$ $\mathrm{N}$ average concentration in effluent was $0.60,0.290 .52$ and $1.75 \mathrm{mg} / \mathrm{L}$, respectively. The $\mathrm{NO}_{2}^{-}-\mathrm{N}$ accumulations

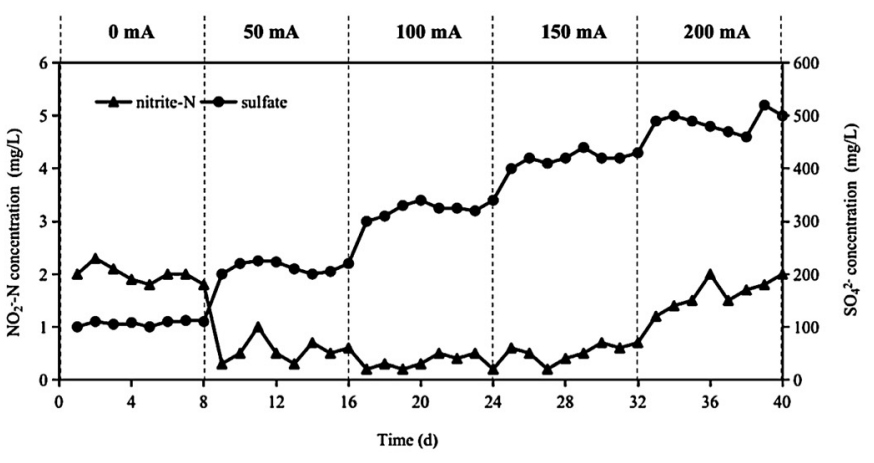

were higher at $50 \mathrm{~mA}$ than 100 and $150 \mathrm{~mA}$, it might be explained by he sensitivity of the enzyme nitrate reductase to such current levels, affecting their activity leading to the large amount of $\mathrm{NO}_{3}{ }^{-}-\mathrm{N}$ to be reduced to $\mathrm{NO}_{2}^{-}-\mathrm{N}$. The terminal $\mathrm{NO}_{2}^{-}-\mathrm{N}$ concentrations under $100 \mathrm{~mA}$ was also significantly lower than the other current intensities. These indicated that optimum current intensity into the reactor not only accelerated the nitrate reduction but also led to the significant increases in nitrite reduction. Results also showed that without electrical stimulation, both rates of increase or decrease of nitrite were generally lower than other conditions that were applied with current. This suggests that the current had a stimulating effect on both nitrate reductase and nitrite reductase. In addition, no 
nitrite was detected in the electrochemical reduction without bacteria, further implying that the microorganisms were the main reason for $\mathrm{NO}_{2}^{-}-\mathrm{N}$ accumulation. Except for the direct influence of current, nitrite reductase might be inhibited by higher concentration of hydrogen gas.

Sulfate concentrations was also showed in Figure 1, with the increase of current, the concentration of sulfate increases. When the applied current intensity was increased incrementally from 0 to $200 \mathrm{~mA}$, the average concentration of sulfate values were $110,225,331,422$ and $507 \mathrm{mg} / \mathrm{L}$, respectively. The maximum sulfate concentration at current intensity was $200 \mathrm{~mA}$. According to previous study, when nitrate was reduced, sulfate production by elemental sulfur based denitrification, this results in a large amount of sulfate accumulation[11]. of current intensity on proportion of hydrogen autotrophic denitrification and sulfur autotrophic denitrification are shown in Figure 2. When no current applied, proportion of sulfur autotrophic denitrification was $47 \%$. When the applied current intensity was increased, the proportion of hydrogen autotrophic denitrification decreased, and the two proportions have almost the same level at 150 and 200 $\mathrm{mA}$. The reason may be that the increase of current intensity has a greater promoting effect on nitrate reductase activity in sulfur autotrophic microorganisms, so more elemental $\mathrm{S}$ in the system is used by sulfur autotrophic microorganisms. At the same time, when the current intensity increases to a certain extent, it has a "hydrogen inhibition" effect on hydrogen autotrophic bacteria.

\subsection{The proportion of hydrogen autotrophic denitrification and sulfur autotrophic denitrification}

Substituting the test data into the above formula, the effect

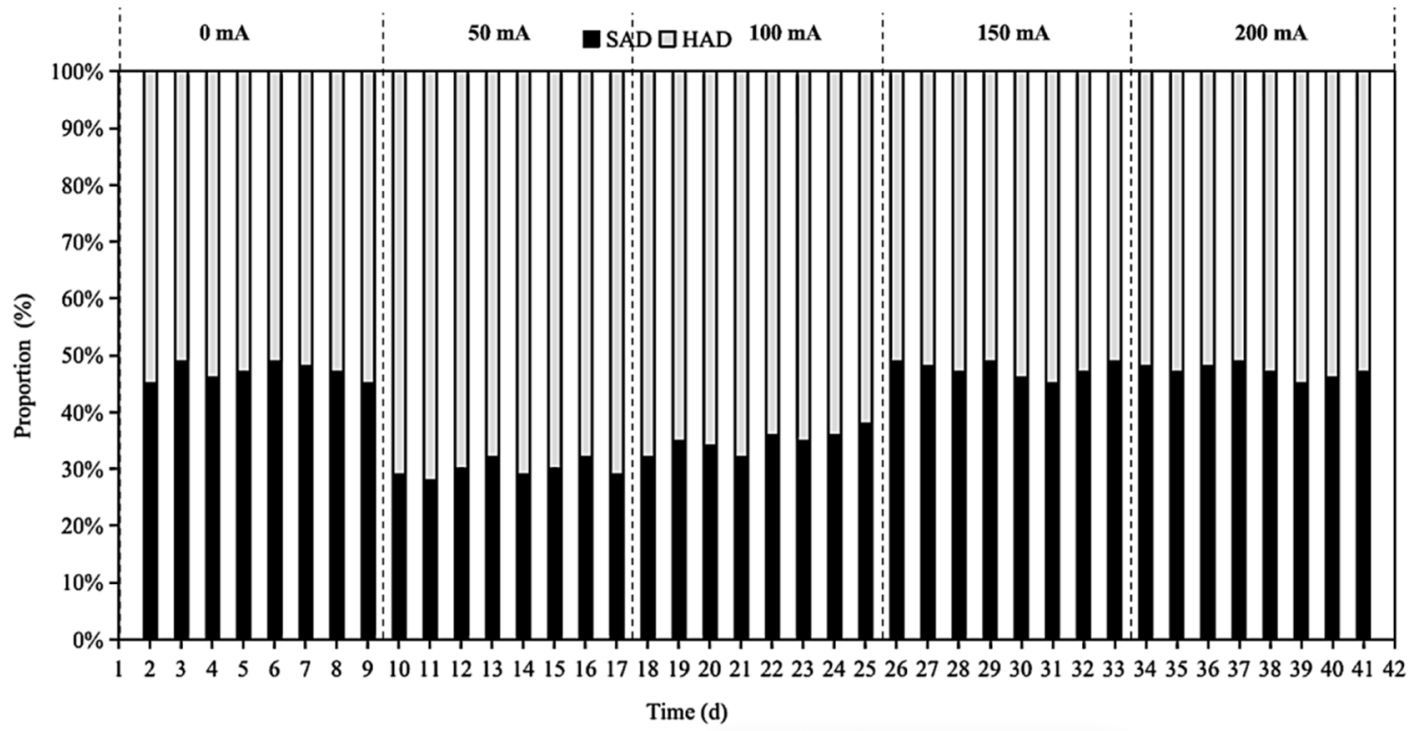

Figure 2. Effect of current intensity on proportion of hydrogen autotrophic denitrification and sulfur autotrophic denitrification

\section{Conclusions}

The biofilm-electrode reactor coupled with sulfur autotrophic denitrifification process (BER-SAD) was used to remove nitrate in groundwater, and the effect of current intensity on the denitrification characteristics of the coupled process was explored. Current intensity had a great influence on the denitrification effect of the coupled process. The maximum nitrate removal efficiency $99.9 \%$ were obtained when temperature was $30{ }^{\circ} \mathrm{C}$, influent nitrate concentration was about $50 \mathrm{mg} / \mathrm{L}$, influent $\mathrm{NaHCO}_{3}$ concentration was $1 \mathrm{~g} / \mathrm{L}$, influent $\mathrm{pH}$ was 7.25 , HRT was $8 \mathrm{~h}$ at the optimum current intensity of $100 \mathrm{~mA}$ in a BER-SAD, at which low nitrite production was obtained. The increase of current intensity can promote the utilization of S by sulfur autotrophic bacteria, resulting in the increase of $\mathrm{SO}_{4}{ }^{2-}$ accumulation with the increase of current intensity in the coupled reactor. With the increase of current intensity, the proportion of hydrogen autotrophic denitrification decreased, while the proportion of sulfur autotrophic denitrification increased.

\section{Acknowledgments}

The authors acknowledge financial support from the Natural Science Foundation of Inner Mongolia (No. 2019BS02006), the Research Start-up Funds for the Chifeng University (No. QDJRCYJ022).

\section{References}

1. Liu H., Chen N., Feng C., Tong S., Li R. (2017) Impact of electro-stimulation on denitrifying bacterial growth and analysis of bacterial growth kinetics using a modified Gompertz model in a bio-electrochemical denitrification reactor. Bioresource Technology, 232: 344-353. 
2. Jin S., Feng C., Tong S., Chen N., Liu H., Zhao J. (2019) Effect of sawdust dosage and hydraulic retention time (HRT) on nitrate removal in sawdust/pyrite mixotrophic denitrification (SPMD) systems. Environmental Science: Water Research and Technology, 5: 346-357.

3. Liang J., Chen N., Tong S., Liu Y., Feng C. (2018) Sulfur autotrophic denitrification (SAD) driven by homogeneous composite particles containing $\mathrm{CaCO}_{3}$ type kitchen waste for groundwater remediation. Chemosphere, 212: 954-963.

4. Adav S.S., Lee D., Lai J.Y. (2010) Enhanced biological denitrification of high concentration of nitrite with supplementary carbon source. Applied Microbiology and Biotechnology, 85(3): 773-778.

5. Chen D., Wei L., Zou Z., Yang K., Wang, H. Bacterial communities in a novel three-dimensional bioelectrochemical denitrification system: the effects of pH. (2016). Applied Microbiology and Biotechnology, 100(15): 6805-6813.

6. Tong S., Zhang B., Feng C., Zhao Y., Chen N., Hao C., Pu J., Zhao L. (2013) Characteristics of heterotrophic/biofilm-electrode autotrophic denitrification for nitrate removal from groundwater. Bioresource Technology, 148: 121-127.

7. Liu H., Tong S., Chen N., Liu Y., Feng C., Hu Q. (2015) Effect of electro-stimulation on activity of heterotrophic denitrifying bacteria and denitrification performance. Bioresource Technology, 196: 123-128.

8. Wei, V., Elektorowicz, M., Oleszkiewicz, J.A. (2011) Influence of electric current on bacterial viability in wastewater treatment. Water Research, 45: 50585062.

9. Wang J., Hao R., Meng C. (2014) Enhanced removal of nitrogen and phosphorus in 3DBER filled with sponge iron and activated carbon . China Water \& Wastewater, 30 (11): 19-23 ( in Chinese).

10. Pu J., Feng C., Liu Y., Li R., Kong Z., Chen N., Tong S., Hao C., Liu Y. (2014) Pyrite-based autotrophic denitrification for remediation of nitrate contaminated groundwater. Bioresource Technology, 173: 117-123.

11. He Y., Wang Y., Song X. (2016) High-effective denitrification of low $\mathrm{C} / \mathrm{N}$ wastewater by combined constructed wetland and biofilm-electrode reactor (CW-BER). Bioresource Technology, 203: 245-251. 